\title{
The evaluation of cytotoxicity and cytokine IL- 6 production of root canal sealers with and without the incorporation of simvastatin: an invitro study
}

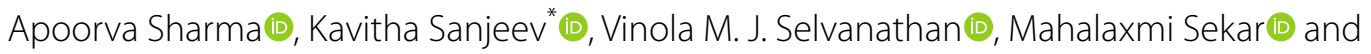
Nikhil Harikrishnan (1)

\begin{abstract}
Background: Freshly mixed root canal sealers when proximate the periapical tissues, trigger varying degrees of cytotoxicity/inflammatory reactions. Simvastatin, a class of the drug statin, is a widely used cholesterol-lowering agent with additional anti-inflammatory activities. This study assessed the effects of simvastatin on cytotoxicity and the release of IL-6 (Interleukin-6) production when incorporated in zinc oxide eugenol and methacrylate resin-based sealers.

Methods: Experimental groups consisted of conventional zinc oxide eugenol and methacrylate based-EndoREZ sealers (ZE \& ER respectively) and $0.5 \mathrm{mg} / \mathrm{mL}$ simvastatin incorporated sealers (ZES \& ERS). L929 mouse fibroblast cells were exposed to freshly mixed experimental sealers and evaluated for cytotoxicity (MTT assay) and inflammation levels (inflammatory marker IL-6 for ELISA) at various time intervals ( $0 \mathrm{~h}, 24 \mathrm{~h}$ and 7 th day). The values were compared to the cell control (CC; L929 cells alone) and solvent control (SC; L929 cells + DMSO) groups. All the experiments were conducted in triplicates and subjected to statistical analysis using IBM SPSS Statistics software. Non parametric tests were conducted using Kruskal-Wallis and Friedman tests for inter-group and intra-group comparisons respectively. Pairwise comparison was conducted by post hoc Dunn test followed by Bonferroni correction. $P$ values $<0.05$ were considered statistically significant.
\end{abstract}

Results: All the experimental groups (ZE, ER, ZES, ERS) exhibited varying degree of cytotoxicity and IL-6 expression compared to the control groups CC and SC. The cell viability for ZE and ER decreased on day 7 as compared to $24 \mathrm{~h}$. ZES and ERS had higher viable cells (75.93\% \& 79.90\%) compared to ZE and ER (54.39\% \& 57.84\%) at all time periods. Increased expression of IL-6 was observed in ZE \& ER $(25.49 \mathrm{pg} / \mathrm{mL} \& 23.14 \mathrm{pg} / \mathrm{mL})$ when compared to simvastatin incorporated ZE \& ER (ZES-12.70 pg/mL \& ERS-14.68 pg/mL) at all time periods. Highest level of cytotoxicity and inflammation was observed in ZE compared to all the other groups on day 7.

Conclusions: Addition of $0.5 \mathrm{mg} / \mathrm{mL}$ of simvastatin to the sealers (ZES and ERS) decreased the cytotoxicity in the freshly mixed state and reduces their inflammatory effect.

Keywords: Cytokine, Cytotoxicity, IL-6 receptor, Inflammation, Root canal sealers, Simvastatin

*Correspondence: kavithasanjeev02@gmail.com Department of Conservative Dentistry and Endodontics, SRM Dental College, Ramapuram, Chennai, Tamil Nadu 600089, India

\section{Background}

Periapical tissue reactions following root canal treatment/or obturation are influenced by numerous factors, 
including pre-existing disease, removal of pulp tissue, cleaning and shaping of the root canal system, obturation technique and the chemical nature of the sealer [1]. Several studies have emphasized that root canal filling materials should be confined within the intra- radicular space $[2,3]$. However, there are circumstances when controlled application is not possible and it may inadvertently extrude into the periradicular area thorough lateral and accessary canals, and apical foramen [4-6]. Evidences claim that, in absence of infections, though the apical extent of the root canal filling materials does not have direct correlation to the treatment outcomes, an inflammatory response with increased postoperative discomfort of varying intensity generally develop in areas where the sealers proximate the apical and periradicular tissues [4-6]. Amongst the various commercially available sealers, zinc oxide eugenol (ZOE) and methacrylate-based sealers (EndoREZ) have evidently shown the highest cytotoxicity, inducing periapical inflammation [7].

During periapical inflammation, along with inflammatory cells namely PMNs (polymorphonuclear leukocyte), lymphocytes and macrophages, there is also an increased release of proinflammatory cytokines, namely interleukins (ILs) $[8,9]$. Following infections and tissue injuries, interleukin 6 (IL-6), is produced immediately and transiently, contributing to host defence through the stimulation of acute phase responses, haematopoiesis and immune reactions [10]. Azuma et al., reported detection of significantly higher levels of IL-6 in in vitro model, and in human inflamed pulp tissue and periapical lesions of endodontic origin. Therefore, IL- 6 has been speculated to be a critical factor in cytokine cascade determining inflammation [11]. Successful endodontic treatment thus necessitates preventing and controlling this inflammation providing a favourable environment for periapical repair and healing.

Statins, 3-hydroxy-3-methyl-glutaryl-coenzyme A (HMG CoA) reductase inhibitors commonly used as an anticholestral drug, are reported to exhibit immunomodulatory, anti-inflammatory and anti-oxidative effects $[12,13]$. Simvastatin a class of drug statin has proven to reduce the cytokine-mediated IL- 6 release in mononuclear cells [14]. Sakoda et al., showed the anti-inflammatory effect of simvastatin on human oral epithelial cells and found decreased IL-6 and IL-8 production [15]. Varying methodological approaches including observational, in vitro, animal, in vivo, randomized clinical studies and meta-analysis have concluded simvastatin's effectiveness in chronic periodontitis when used locally and systemically, in non-surgical, surgical periodontal therapy and as oral administration, as an antimicrobial agents against oral microorganisms [16, 17]. Various animal modelbased studies and clinical trials examined the effect of statins on the pathogenesis of periapical lesions and were conclusive about the role of statins in bone formation for e.g. in osseointegration of implants, as a local application in extraction sites to prevent alveolar bone resorption [16, 18-20]. Collectively, literature evidence of various clinical trials states that, rather than systemic administration, local application of statins have significantly enhanced beneficial effects on dental and oral health [16, 17]. Apart from its anti-inflammatory effect, recent widespread evidence proposes that, statins increase the gene expression of BMP-2 (bone morphogenic protein-2) and inhibit MMPs (matrix metalloproteins), thereby stimulating differentiation of osteoblastic bone marrow stem cells, enhancing wound healing $[16,21,22]$. Thus, the rationale aiding the use of statin through local administration accounts for its enhanced bioavailability.

In this context, whether the addition of simvastatin to the currently used root canal sealer is capable of reducing sealer induced cytotoxicity and inflammation needs to be evaluated. Hence the aim of this in vitro study was to comparatively evaluate the effects of the addition of simvastatin on the cytotoxicity and anti-inflammatory effect of ZOE and methacrylate sealer. The null hypothesis is that the addition of simvastatin will not reduce the cytotoxicity and inflammation caused by ZOE and methacrylate resin-based sealers.

\section{Methods}

The research protocol was presented to Institutional Review Board (IRB) and approval was obtained SRMDC/ IRB/2018/MDS/No. 301.

\section{Preparation of simvastatin}

Dimethyl sulfoxide (DMSO), phosphate-buffered saline (PBS) and simvastatin powder were procured from Sigma-Aldrich St.Louis, MO, USA. 1:1 ratio of DMSO: PBS solution was prepared and set at $\mathrm{pH}$ 7.2. Simvastatin powder $(0.5 \mathrm{mg}$ ) (Lot no: 0000048519,0000040533$)$ was weighed using a digital weighing scale (BSA 224S CW, Sartorius, Gottingen, Germany.). The weighed simvastatin powder was incorporated into the prepared solution to obtain $0.5 \mathrm{mg} / \mathrm{mL}$ solution of simvastatin $[6,23,24]$.

\section{Preparation of test samples}

Equal amounts of base and catalyst of ZOE sealer (Tubliseal, Kerr, Romulus, MI, USA, Lot no: 6807867) were dispensed on the mixing pad and mixed by spatulating the pastes for one minute to obtain $1 \mathrm{~mL}$ of the sealer (Group-ZE- Zinc oxide Eugenol). $1 \mathrm{~mL}$ of EndoREZ sealer (Lot no: BH 8 BC; Ultra dent Products, South Jordan, UT, USA.) was dispensed on the pad from the dual-barrel syringe through the mixing tip (Group-ER- EndoREZ) [6, 
Table 1 Experimental sealers, their composition and manipulation

\begin{tabular}{|c|c|c|c|c|c|}
\hline S. no & Sealers & $\begin{array}{l}\text { Manufacturer's } \\
\text { company name }\end{array}$ & Lot no & Composition & Manufacturer's instructions \\
\hline 1 & $\begin{array}{l}\text { Zinc Oxide Eugenol sealer } \\
\text { (Tubliseal EWT) }\end{array}$ & Kerr, USA & $6,807,867$ & $\begin{array}{l}\text { Base: } \\
\text { Zinc oxide Barium sulfate Lecithin } \\
\text { Corn starch Mineral oil } \\
\text { Catalyst: Polypale resin Eugenol } \\
\text { Thymol } \\
\text { Accelerator: } \\
\text { 4-Allyl-2-methoxyphenol, Dimeric acid } \\
\text { resin }\end{array}$ & $\begin{array}{l}\text { Mix equal volume units (1:1) of base and } \\
\text { catalyst }\end{array}$ \\
\hline 2 & $\begin{array}{l}\text { Methyl methacrylate sealer } \\
\text { (EndoRez) }\end{array}$ & $\begin{array}{l}\text { Ultradent } \\
\text { Products, South } \\
\text { Jordan, UT }\end{array}$ & $\mathrm{BH} 8 \mathrm{BC}$ & $\begin{array}{l}\text { Zinc oxide, Barium sulphate, Resins 30\% } \\
\text { UDMA resin, Pigments }\end{array}$ & $\begin{array}{l}\text { Twist the dual barrel syringe counter } \\
\text { clockwise to dispense the material }\end{array}$ \\
\hline
\end{tabular}

25]. The composition of the experimental sealers is mentioned in Table 1.

Groups ZES \& ERS (simvastatin incorporated ZOE and Endo REZ sealers respectively) were prepared by incorporating $0.5 \mathrm{mg} / \mathrm{mL}$ simvastatin to ZOE and EndoREZ sealers respectively and spatulated $1 \mathrm{~mL}$ of Dulbecco Modified Eagle Medium (DMEM) (Gibco, Thermo Fisher Scientific, Waltham, MA, USA) with each of the sealer followed by placement in a cyclomixer (CM101 Plus, Remi, Mumbai, India) to obtain a uniform mix; $0.5 \mathrm{~mL}$ of this solution was taken and again mixed with $0.5 \mathrm{~mL}$ DMEM to obtain $1 \mathrm{~mL}$ of the sealer solution to be subjected to various evaluations [6].

Cytotoxicity and IL-6 assessment were carried out using MTT (3-(4,5-dimethylthiazol-2-yl)-2,5-diphenyltetrazoliumbromide) and ELISA (enzyme-linked immunoassay) assays respectively at various time intervals $(0 \mathrm{~h}, 24 \mathrm{~h}$ and 7 th day) for all the test samples.

\section{Cell culture}

L929 mouse fibroblast cells (Lot no: ACC85011425; NCCS, Pune, India) were cultured using $25-\mathrm{cm}^{2}$ culture flasks containing $2 \mathrm{mmol} / \mathrm{L}$ L-glutamine $10 \%$ fetal bovine serum, $100 \mu \mathrm{g} / \mathrm{mL}$ streptomycin, and $100 \mathrm{U} / \mathrm{mL}$ penicillin (all from Gibco, Thermo Fisher Scientific, Waltham, MA, USA). Cultures were kept in an incubator (BBD 6220; Thermo Fisher Scientific, Waltham, MA, USA) at $37^{\circ} \mathrm{C}$ under ambient pressure and $5 \% \mathrm{CO}_{2}$ atmosphere. Cells were used from the $3 \mathrm{rd}$ passage till the 20 th passage [26]. Confluent cell monolayers were trypsinized, and the cells that were harvested, were used for cytotoxicity experiments.

\section{Cytotoxicity assessment}

Assessment of the toxic effects of the tested materials on human periodontal ligament fibroblasts was performed using 3-(4,5-dimethylthiazol-2-yl)-2,5-diphenyltetrazolium- bromide (MTT assay), Live/ Dead staining using Calcein $\mathrm{AM}$ and Ethidium homodimer-1(EHD) and Flow cytometry following double staining with Calcein AM/ Propidium Iodide (PI).

\section{MTT assay}

This method enables determining cell viability and proliferation based on the mitochondrial activity of succinate dehydrogenase. Ninety six well plates (Costar, Corning, NY, USA) were taken for seeding exponentially growing L929 mouse fibroblast cells at a concentration of $1 \times 10^{4}$ cells/well. After $24 \mathrm{~h}$, the culture medium was cleared out and the cells were incubated in freshly prepared experimental sealers $(0.5 \mu \mathrm{L}$ of the experimental solution added to the cells using a micropipette) for $24 \mathrm{~h}$ at $37{ }^{\circ} \mathrm{C}$ in an atmosphere of $5 \% \mathrm{CO}_{2}$. For the experimental groups, cells were incubated with $0.2 \mathrm{mg}$ sodium lauryl sulphate (Life Technologies, Mumbai, India) in DMEM medium, while for the cell control group (Group CC- L929 cells alone) and solvent control group (Group SC- L929 cells + DMSO), cells were incubated in culture medium alone and with DMSO and culture medium respectively. $50 \mu \mathrm{L}$ of $0.5 \%$ 3-(4,5-dimethylthiazol-2-yl)-2,5-diphenyltetrazoliumbromide (Sigma- Aldrich, St. Louis, MO, USA) was added to each well and the plates were then incubated for approximately $2 \mathrm{~h}$, at $37{ }^{\circ} \mathrm{C}$ in a humidified atmosphere of $5 \% \mathrm{CO}_{2}$ in air. The conversion of the yellow 3-(4,5-dimethylthiazol-2-yl)-2,5-diphenyltetrazoliumbromide to the purple formazan by the cellular $\mathrm{NAD}(\mathrm{P})$ reflux was measured. MTT dye was removed after incubation, and $100 \mu \mathrm{L}$ isopropanol (Life Technologies, Mumbai, India) was added to dissolve the formazan crystals. Plates were gently shaken at room temperature to ensure formazan solubilization, and transferred to the spectrophotometer (Multiskan Sky Microplate Spectrophotometer; Thermo Fisher Scientific, Waltham, MA, USA). The viability of the cultured cells was determined 
at a wavelength of $570 \mathrm{~nm}$. All the experiments were done in triplicates [6].

The percentage of cell viability was then calculated as: bonded with the conjugated biotin-interleukin. After $1 \mathrm{~h}$ at room temperature, they were rinsed again with distilled water and the samples were assessed at $450 \mathrm{~nm}$

$$
\text { Percentage of cell viability }=\frac{\text { Absorbance of treated cells at } 570 \mathrm{~nm}}{\text { Absorbance of control cells at } 570 \mathrm{~nm}} \times 100 \%
$$

\section{Live and dead cell assay}

The advantage of the live/dead staining procedure applied, is that the respective red and green fluorescence of EHD and Calcein are easily discernable by florescence microscopy. L929 fibroblast cells were seeded in 6 well plates at the density of $1 \times 10^{6}$ cells/well). After being cultured for $24 \mathrm{~h}$, live/dead viability assay kit (Invitrogen Life Technologies, Carlsbad, CA). Cells were incubated with dye for $30 \mathrm{~min}$ and were washed with PBS. Live cells were stained green with $2 \mathrm{mmol} / \mathrm{L} \mathrm{Cal-}$ cein AM (Invitrogen Life Technologies, Carlsbad, CA), and dead cells were marked red with $4 \mathrm{mmol} / \mathrm{L}$ ethidium homodimer-1. They were observed under inverted phase contrast fluorescence microscopy $(20 \times$ magnification). Viable cells exhibited green fluorescence while the dead cells appeared red. The percentage of the live cells were calculated using Image J software.

\section{Flow cytometry analysis}

The Live/Dead assay was determined by using CalceinAM /Propidium iodide Double stain kit (G-Biosciences, USA). After incubation with control and experimental group of different composition of sealers, the cells $(5 \times 105)$ were harvested and suspended in $1 \times$ phosphate buffered saline (PBS). Then the cells were incubated with Calcein-AM $(50 \mu \mathrm{M}) /$ propidium iodide (PI) $(10 \mu \mathrm{g} / \mathrm{ml})$ diluted in culture medium for $30 \mathrm{~min}$ in the dark. Cells were then washed with ice-cold $1 \times$ PBS and immediately resuspended in sheath fluid in BD-FACS analysis tube for experiment. The FACS was performed using BectonDickinson canto II (BD Biosciences, USA) for analysis. The data were analyzed by FlowJo (version 7.6.1).

\section{Cytokine detection}

The samples of groups were prepared according to the previous protocol. The collected culture suspensions were preserved in microtubes at $-20{ }^{\circ} \mathrm{C}$. IL-6 kit (DY506, DuoSet; R \& D systems, MN, USA) containing 96 well plates were used for determining the fibroblast cytokine level. Anti-IL-6-monoclonal antibody was added to each well of the ELISA plate. The samples of IL- 6 were then conjugated with biotin and added to wells and were maintained for $2 \mathrm{~h}$ at room temperature. The samples were thoroughly rinsed with distilled water to eliminate any unbound compounds. Streptavidin HRP (Thermo Fisher Scientific, Waltham, MA, USA) was added to be using spectrophotometer, IL- 6 was assessed at $0 \mathrm{~h}, 24 \mathrm{~h}$ and 7 th day. All the experiments were done in triplicates [27].

\section{Statistical analysis}

At least three independent experiments were performed for each parameter and the mean value was used for statistical analysis. The data was analysed using IBM SPSS Statistics software (IBM Corp., Armonk, NY, USA). The results were presented as mean \pm standard errors (SE). Parametric and Non parametric tests were conducted using students T test, Kruskal-Wallis and Friedman tests for inter-group and intra- group comparisons respectively. Pairwise comparison was conducted by post hoc Dunn test followed by Bonferroni correction. $P$ values $<0.05$ were considered statistically significant.

\section{Results}

The mean cell viability levels (\%) and the mean cytokine (IL-6) expression [picogram $/ \mathrm{mL}$; $(\mathrm{pg} / \mathrm{mL})$ ] for all the groups at different time periods of $0 \mathrm{~h}, 24 \mathrm{~h}$ and 7 th day are given in Table 1 and 2. Graphical representation of the same are given in Figs. 1 and 2 respectively. Figures 3 and 4 represents live/dead assay of all the groups at different time periods ( $24 \mathrm{~h}$ and 7 th day). Figures 5 and 6 represents histogram of flow cytometry analysis of all the groups.

Table 2 Mean \pm SD of percentage of viable cells of all the groups at different time periods

\begin{tabular}{llll}
\hline Groups & $\mathbf{0} \mathbf{h}$ & $\mathbf{2 4} \mathbf{h}$ & 7th day \\
\hline CC & $100.00 \pm 0.000$ & $100.00 \pm 0.000$ & $100.00 \pm 0.000$ \\
SC & $99.024 \pm 0.001$ & $92.740 \pm 0.049$ & $87.943 \pm 0.017$ \\
ZE & $96.042 \pm 0.002^{\dagger}$ & $73.315 \pm 0.299$ & $54.395 \pm 0.354^{\dagger}$ \\
ER & $99.242 \pm 0.004$ & $68.569 \pm 0.516^{\dagger}$ & $57.847 \pm 0.021$ \\
ZES & $99.513 \pm 0.021$ & $82.402 \pm 0.371$ & $75.933 \pm 0.049$ \\
ERS & $99.966 \pm 0.014$ & $81.380 \pm 0.314$ & $79.905 \pm 0.048$
\end{tabular}

$\mathrm{n}=3$, $(P>0.05)$; † Statistically significant. († represent the intergroup comparative values that are statistically significant against the control groups) h-hours CC-Cell control; SC-Solvent control; ZE-Zinc Oxide Eugenol sealer; ER-EndoREZ sealer; ZES \& ERS- Simvastatin incorporated Zinc oxide eugenol and EndoREZ respectively 


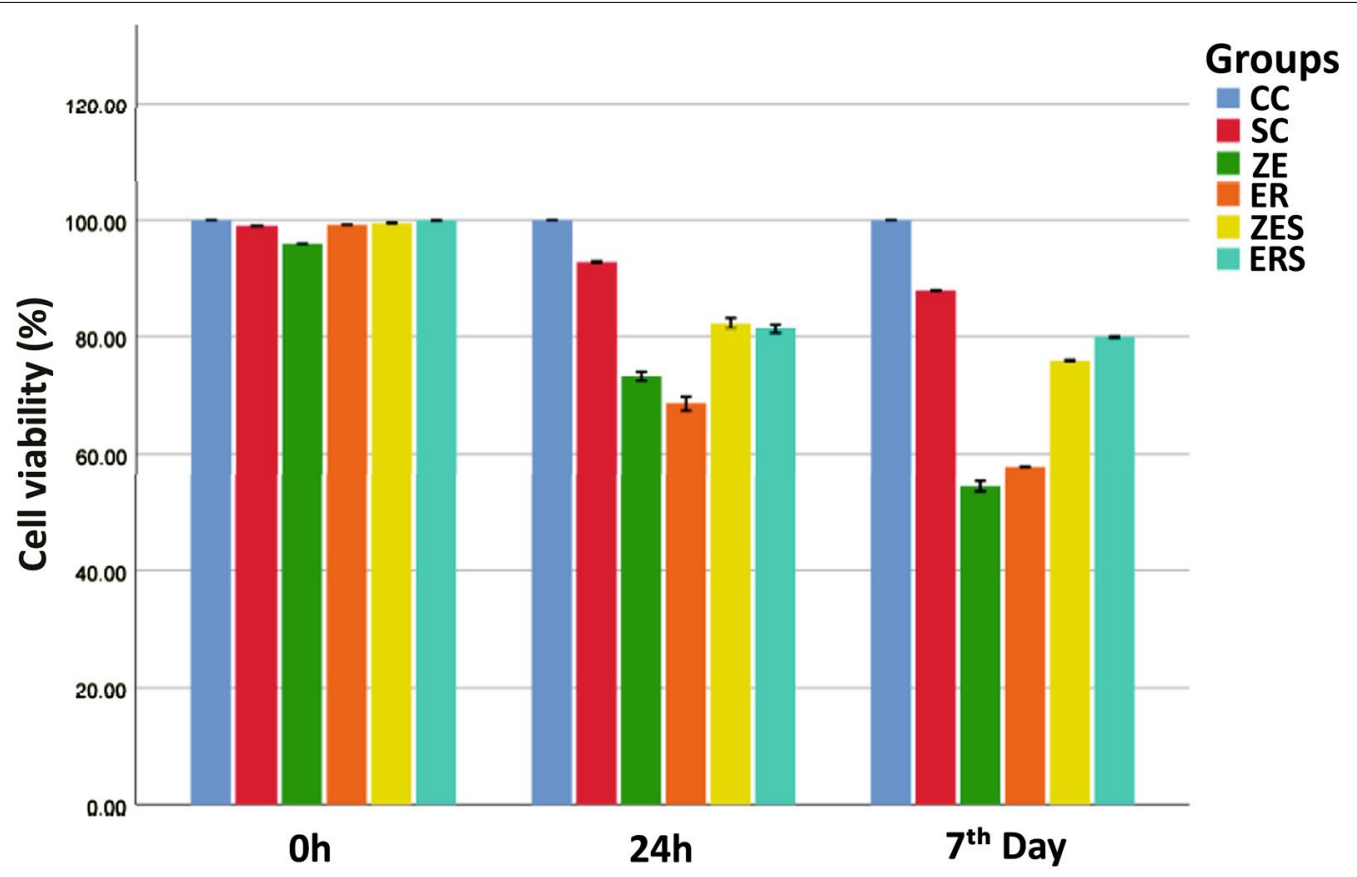

Fig. 1 Graphical representation of percentage of cell viability of all the groups at various time intervals (Mean \pm SD). Footnotes: h-hours CC-Cell control; SC-Solvent control; ZE-Zinc Oxide Eugenol sealer; ER-EndoREZsealer; ZES \& ERS- Simvastatin incorporated Zinc oxide eugenol and EndoREZ respectively

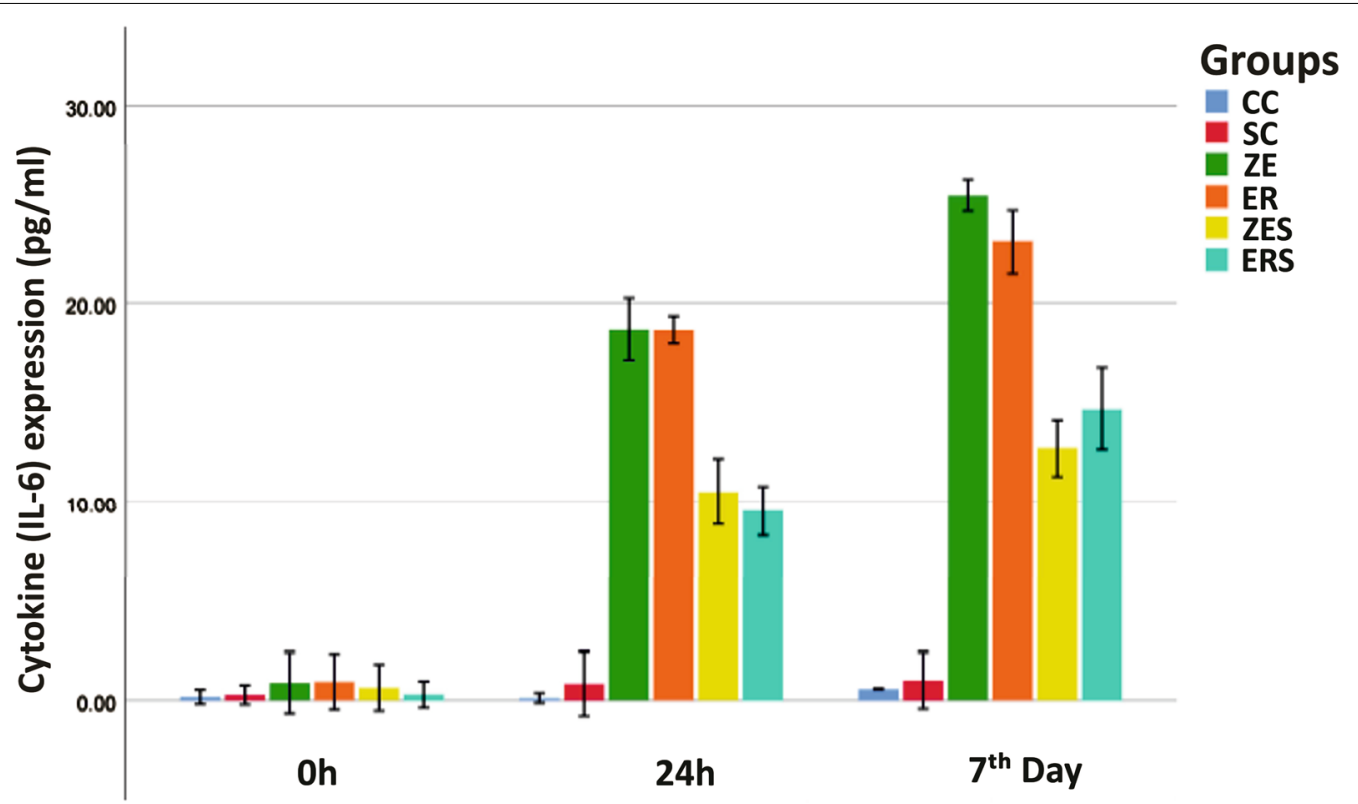

Fig. 2 Graphical representation of cytokine (IL-6) expression $(\mathrm{pg} / \mathrm{mL}$ ) of all the groups at various time intervals (Mean \pm SD). Footnotes: IL-6-Interleukin-6; pg/mL_-picogram/millilitre h-hours; CC-Cell control; SC-Solvent control; ZE-Zinc Oxide Eugenol sealer; ER-EndoREZ sealer; ZES \& ERS- Simvastatin incorporated Zinc oxide eugenol and EndoREZ respectively 

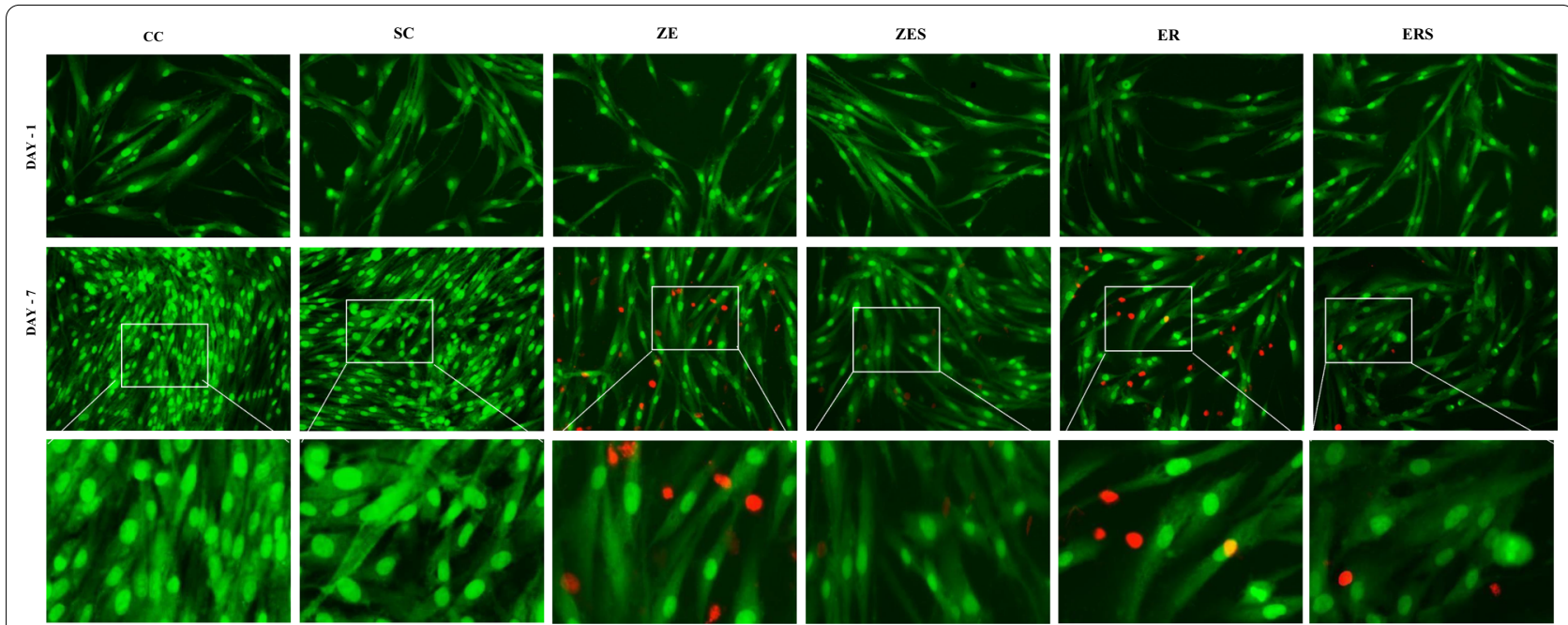

Fig. 3 Live/dead assay: Representative live/dead cell images of experimental sealers with and without simvastatin on L929 cells at $24 \mathrm{~h}$ and day 7 of culture, observed under phase contrast fluorescence microscopy at $20 \times$. The bottom row shows the enlarged images of 7 th day. Live cells stained green, and dead cells shown in red. In all the groups, the live cells were abundant and few dead cells were noted in ZE,ER and ERS

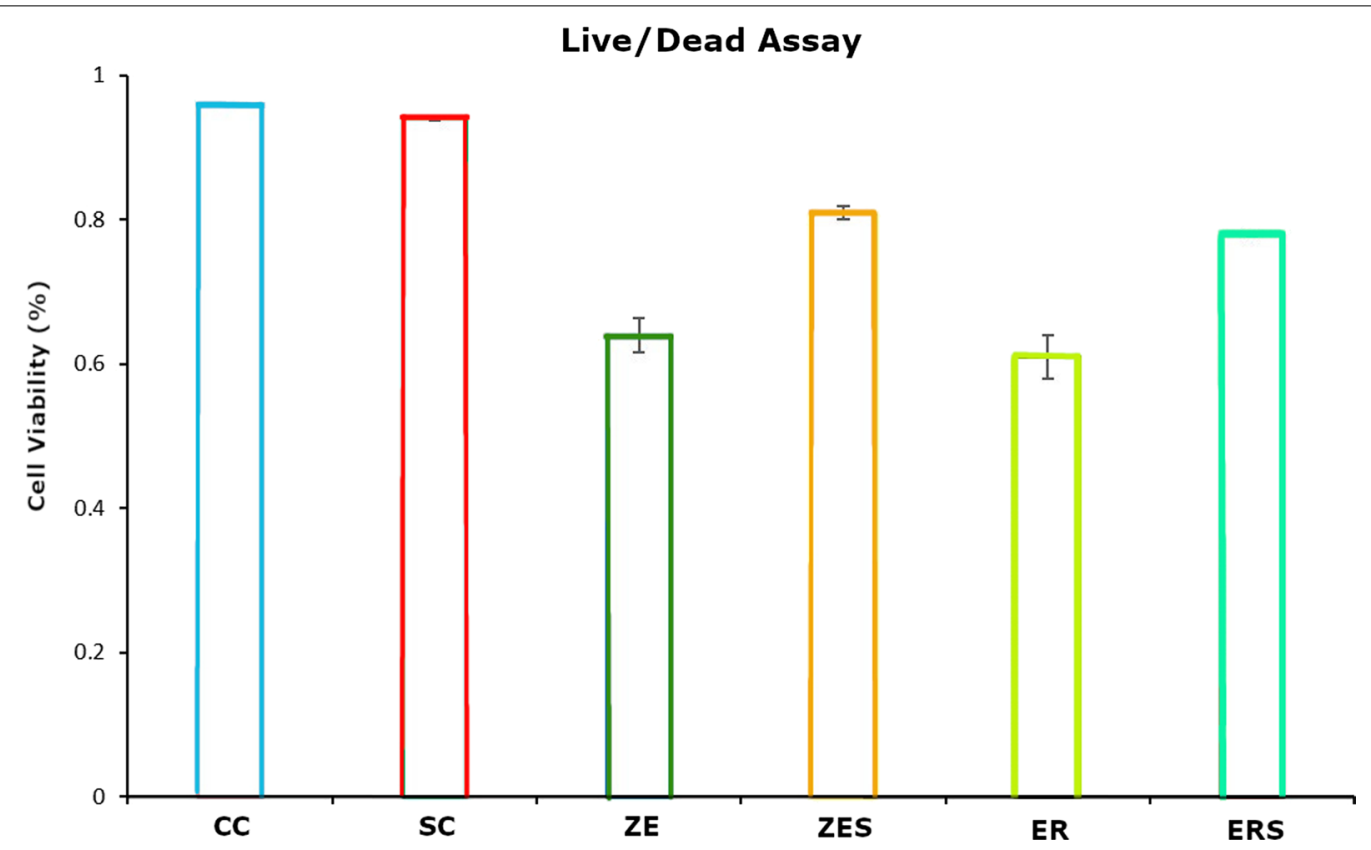

Fig. 4 Data represent the mean \pm standard deviation of experiments with triplicates $(p<0.05)$. Control groups (CC \& SC) show the highest viable cells (\%) while ZE and ER (without simvastatin) show the lowest percentage of viable cells

\section{MTT assay}

The cell control (CC) and solvent control (SC) groups were found to have increased cell viability at $24 \mathrm{~h}$ and 7 th day.

ZE and ER showed decreased cell viability as compared to the control groups at $24 \mathrm{~h}$ till the 7 th day. The cell viability for ZE and ER was $73.31 \%$ and $68.56 \%$ at
$24 \mathrm{~h}$ which decreased to $54.39 \%$ and $57.84 \%$ after 7 th day respectively. ZE was found to have least cell viability count (high cytotoxicity) by the end of the experimentation on 7th day. ZES and ERS were found to have higher cell viability counts than $\mathrm{Z}$ and ER at all the time periods. Cell viability for ZES and ERS were found to be $75.93 \%$ and $79.90 \%$ respectively by the end of the 

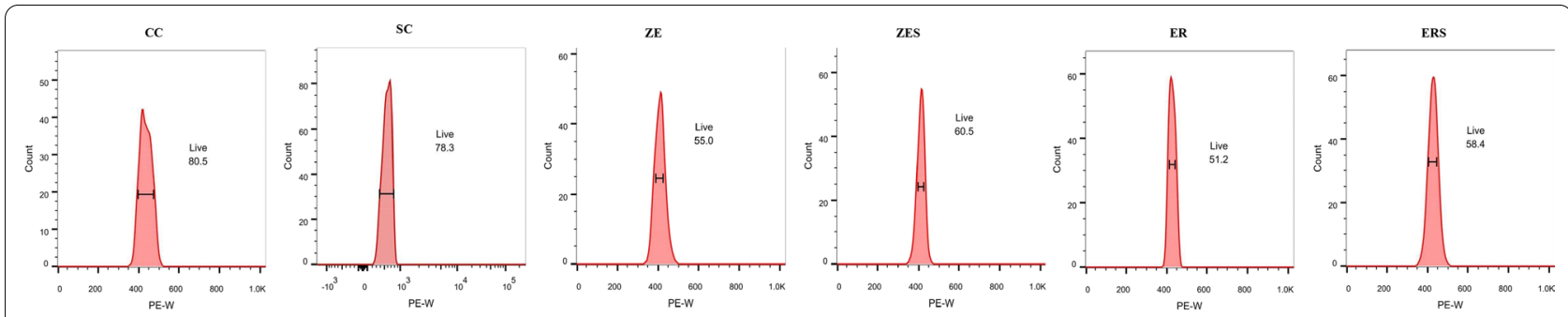

Fig. 5 Cell viability by flowcytometry analysis. Histograms of flow cytometry shows the fluorescence intensity of calcian-AM. They represent the amount of cell proliferation and cell viability following 7 days. The histograms peaks indicates the percentage of live cells present in control and experimental groups

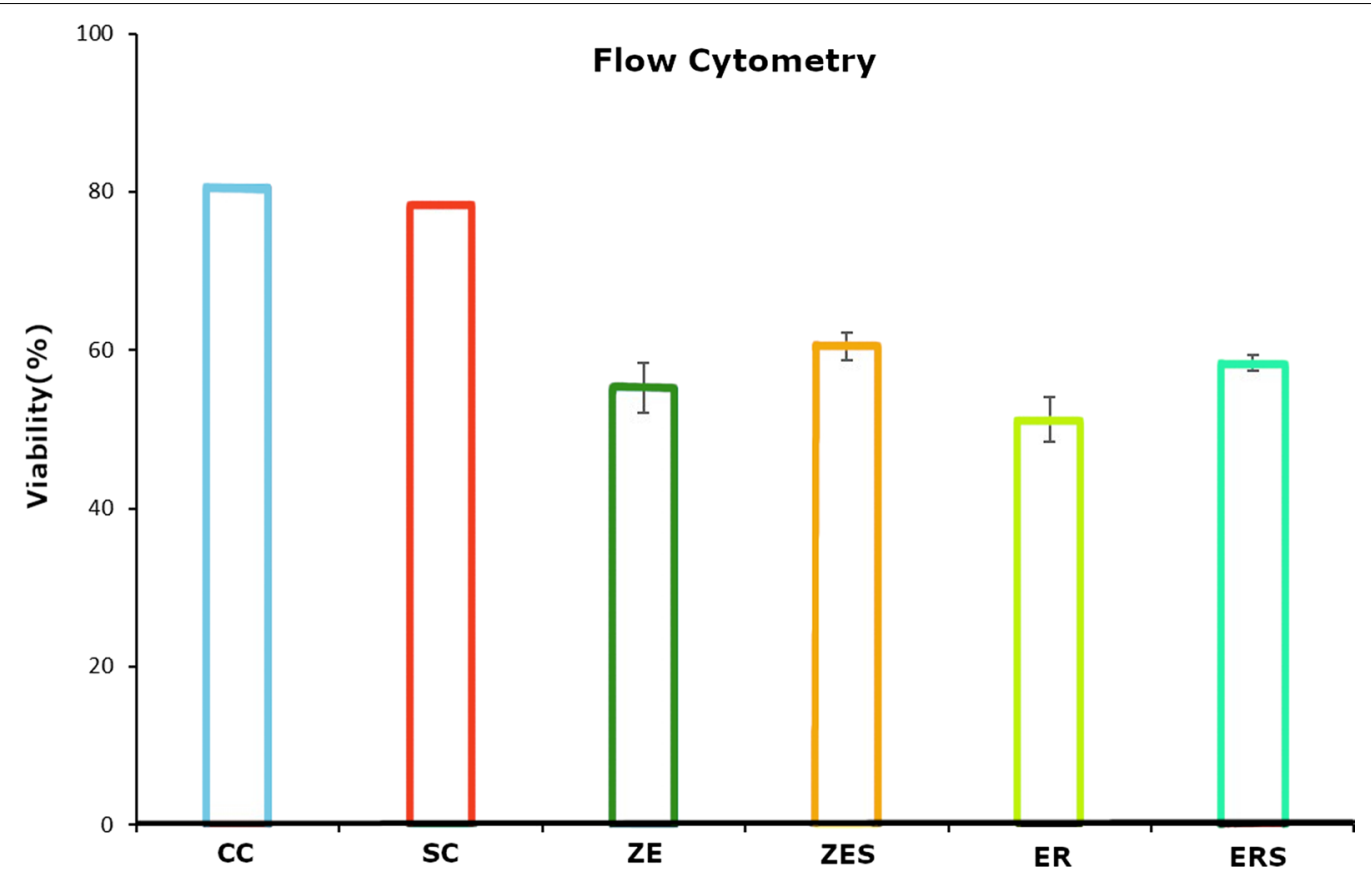

Fig. 6 Data represents graphical representation of viability of cells among all the groups, following flow cytometer analysis.Control groups (CC\&SC) show the highest while sealer groups without simvastatin (ZE\&ER) show the lowest

analysis. On 7th day, the level of cell viability can be stated in the descending order as-

$$
\mathrm{CC}>\mathrm{SC}>\mathrm{ERS}>\mathrm{ZES}>\mathrm{ER}>\mathrm{ZE} \text {. }
$$

\section{Live/dead staining and flow cytometry}

In all the experimental groups, live cells were abundant (stained green), which increased from $24 \mathrm{~h}$ to day 7 . Few dead cells (stained red) were observed in ZE, ER and least in ERS. The histogram peaks in flow cytometry denoted higher number of live cells in simvastatin incorporated sealers (ZES \&ERS) compared to the sealer alone groups (ZE\&ER).

\section{Cytokine detection}

The cell control (CC) and solvent control (SC) groups for DMSO was found to have the least expression of IL-6 at all time periods.

$\mathrm{ZE}$ and ER showed significantly increased amount of IL- 6 as compared to the control groups at $24 \mathrm{~h}$ till the 7 th day. The amount of IL- 6 for ZE and ER was found to be $25.49 \mathrm{pg} / \mathrm{mL}$ and $23.14 \mathrm{pg} / \mathrm{mL}$ respectively on the 7 th day of evaluation, compared to $12.70 \mathrm{pg} / \mathrm{mL}$ and $14.68 \mathrm{pg} / \mathrm{mL}$ for ZES and ERS respectively. Therefore, lesser inflammation can be interpreted for simvastatin incorporated sealers compared to ZE and ER. On 7th day, the level of inflammation (detection of IL-6) can be arranged in the decreasing order as: 
$\mathrm{ZE}>\mathrm{ER}>\mathrm{ERS}>\mathrm{ZES}>\mathrm{SC}>\mathrm{CC}$.

Simvastatin modified sealers (ZES \& ERS) were found to have higher cell viability and lower IL-6 expression compared to ZE \& ER.

\section{Discussion}

Among the sealers tested in the present study, the addition of simvastatin significantly reduced the severity of sealer-induced cytotoxicity, hence, the null hypothesis was rejected. Cytotoxicity evaluation is inevitable with regard to biocompatibility of a newly modified material that is being considered for clinical usage, though the additive component is biocompatible on its own [28]. The literature evidence shows that a considerable variation exists in the outcomes of studies testing the cytotoxicity of the root canal sealers and the effects of simvastatin. This could be attributed to the assessment at different dilutions and concentrations, different techniques (cell cultures systems or animals), different composition of incorporated materials and evaluation at different time intervals. Root canal sealers are inserted into the canal in a freshly mixed state. During the unset and unpolymerized condition, the unreacted or partially reacted components may leach out provoking a local response. And, the leaching of potentially toxic components may continue even after setting of the material. Hence different time intervals were studied to evaluate whether these materials remain cytotoxic and induce inflammation or whether they lose the potential and heal $[28,29]$. In order to analyse the cytotoxicity levels solely by the experimental materials and to remove a confounding factor, two separate control groups were added for comparison namely cell control (CC) and the solvent control (SC) for DMSO, since it has been found to show some amount of cytotoxicity on its own [30-32].

Table 3 Mean \pm SD of cytokine (IL-6) expression (pg/mL) of all the groups at different time periods

\begin{tabular}{llcc}
\hline Groups & $\mathbf{0} \mathbf{h}$ & $\mathbf{2 4} \mathbf{h}$ & \multicolumn{1}{l}{ 7th day } \\
\hline CC & $0.1693 \pm 0.139$ & $0.1119 \pm 0.095$ & $0.5476 \pm 0.010$ \\
SC & $0.2643 \pm 0.186$ & $0.8024 \pm 0.634$ & $0.9714 \pm 0.557$ \\
ZE & $0.8500 \pm 0.603$ & $18.7000 \pm 0.622^{\dagger}$ & $25.4952 \pm 0.307^{\dagger}$ \\
ER & $0.9071 \pm 0.545$ & $18.6809 \pm 0.267^{\dagger}$ & $23.1476 \pm 0.646$ \\
ZES & $0.6167 \pm 0.455$ & $10.5190 \pm 0.657$ & $12.7048 \pm 0.578$ \\
ERS & $0.2833 \pm 0.255$ & $9.5571 \pm 0.495$ & $14.6810 \pm 0.825$ \\
\hline
\end{tabular}

$\mathrm{n}=3,(P>0.05)$. ${ }^{\dagger}$ Statistically significant. ( ${ }^{\dagger}$ Represent the intergroup comparative values that are statistically significant against the control groups)

IL-6-Interleukin-6; pg/mL-picogram/millilitre

h-hours; CC-Cell control; SC-Solvent control; ZE-Zinc Oxide Eugenol sealer; ER-EndoREZ sealer; ZES \& ERS- Simvastatin incorporated Zinc oxide eugenol and EndoREZ respectively
The observations of the present study signify the high level of cytotoxicity and increased expression of IL- 6 of both ZE and ER in freshly mixed state (Tables 2 and 3; Figs. 3 and 5). This is in accordance with previous studies that observed that zinc oxide eugenol and Endo REZ presented significant cytotoxicity to the cultured cells $[33,34]$. ZOE sealers being highly water soluble, dissolution of the material occurs invariably when it comes in contact with the tissue fluids (a reaction seen commonly with materials that set by an acid base reaction, e.g. Tubli-seal).The release of unreacted components like zinc ions, benzyl alcohol, methyl salicylic acid, and rosin could have contributed to cytotoxicity and inflammation at $24 \mathrm{~h}$. Additionally, the release of free eugenol from the freshly mixed paste could have interfered with the cytoplasmic membrane, inhibiting cell respiration, contributing to cytotoxicity and increased IL- 6 release in ZE [6].

In ER, increased cytotoxicity in the first $24 \mathrm{~h}$, could be due to initial outburst of elutes, namely the urethane dimethacrylate (UDMA), zinc and barium. UDMA, a known toxic agent is reported to cause intracellular glutathione depletion at low concentrations [6]. At high concentrations, it causes oxidative stress in the periapical region due to production of ROS [35]. Zinc and barium could have contributed by provoking a granulomatous reaction in the surrounding tissues [36, 37]. Up-regulation of cytokine, namely IL-6 was observed denoting persistent inflammation relating to the slow breakdown and extended setting time of EndoREZ sealer [38, 39]. This was evident with the lesser number of viable cells observed under fluorescent microscope and flow cytometry analysis for both the groups (Figs. 3, 4, 5, 6).

In actuality, time of exposure significantly influences the biocompatibility of dental resins. Though the cytotoxicity gradually lessened after $24 \mathrm{~h}$, it persisted up to day 7 . This could be due to continued release of materials over this period substantiating the further decrease in the percentage of cell viability noted in ER. Moreover, Ashraf et al, have stated that the cytotoxic properties of EndoREZ are less affected by its setting and that the material continued releasing highly toxic agents even after complete setting [40]. This explains the continued cytotoxicity exerted by ER in this present study.

At $24 \mathrm{~h}$, among ER and $\mathrm{ZE}$, decreased cell viability was observed in ER compared to ZE, though not statistically significant $(P>0.05)$. Similar to our findings, Sousa et al., and Konjhodzic-Pric et al., reported high toxicity of ER $[41,42]$. But at day 7, though both ER and ZE were cytotoxic, lesser cell viability was observed in $\mathrm{ZE}$ as compared to ER which was statistically insignificant $(P>0.05)$. Several histopathological and X-ray microanalyses of tissues in contact with ZOE-based materials, have revealed that they were more resistant to fragmentation for 
phagocytosis by interfering with the macrophage adherence, whereas ER requires more energy to be phagocytosed once extruded [43].

Simvastatin incorporated sealers, namely ZES and ERS showed increased cell viability at $24 \mathrm{~h}$ and 7 th day compared to $\mathrm{Z}$ and ER (Table 2; Figs. 3, 4, 5, 6). This observation has been substantiated by the study done by Zhang et al., which reports improved biocompatibility of collagen coated polyethylene terephthalate scaffolds incorporated with simvastatin [44]. Simvastatin induced proliferation of bone marrow stromal cells, high alkaline phosphatase activity, osteoblastic differentiation, more mineralization deposition, and increased expression of osteoblast-related genes like osteocalcin, runt-related transcription factor 2 , bone morphogenetic protein-2, and vascular endothelial growth factor than the other tested groups [44]. In addition Stein et al., and Varalakshmi et al., affirmed the positive effect of simvastatin on cellular differentiation, proliferation, and expression of growth factors, promoting various biological functions like angiogenesis and osteogenesis [44-48].

Sealer induced cytotoxicity results in the formation of reactive oxygen species (ROS), which in turn creates an oxidative stress in the tissues leading to an inflammatory response. Thus, cytotoxicity results in a cascade of inflammatory reactions in the tissues [6]. Mevalonate is the precursor of compounds that serve as lipid attachments to GTPases such as Rho, Rac, and Ras that mediate a number of inflammatory reactions such as NF- $\mathrm{kB}$, activation of ROS and suppression of endothelial nitric oxide synthase which are dependent on isoprenoid production. It was observed that statins exert their effects by suppressing the downstream synthesis of molecules in the mevalonate pathways, mediated through the inhibition of small GTPase prenylation and isoprenoid production $[15,49]$. This inhibition of isoprenoids supresses IL-6, IL-1ß, TNF- $\alpha$ (tumour necrosis factor) production [12, 49]. In this study, substantial reduction in the expression of IL-6 levels in ZES and ERS compared to ZE and ER explains the role played by simvastatin in reducing inflammation $[15,50-53]$. These beneficial effects of simvastatin are concentration dependent [54]. $0.5 \mathrm{mg}$ of simvastatin has been reported to fall within safe limits with potential to reduce inflammation and to induce new bone formation at resorption sites [15, 55-57].

Moreover, it is interesting to note that improved healing outcomes of endodontically treated teeth with preoperative lesions were noted in patients who were already under medication with simvastatin for their systemic condition. Statins are said to act by stimulating growth factors like VEGF, and subsequent inhibition of RANKL-induced NF- $\mathrm{KB}$ activation pathway. This in turn would suppress osteoclastogenesis and MMP-9 resulting in better healing potential, which would otherwise induce bone resorption [29, 58]. Hence the local delivery of simvastatin as designed in this study would by all means have a better effect on the tissues. Despite the favourable outcomes in the materials tested, further investigations are required to acquire valuable information on the physicochemical behaviour of this modified sealer formulation in order to be deemed appropriate for clinical use.

\section{Conclusions}

Within the limitations of this in vitro study, it can be concluded that, the addition of simvastatin reduced the cytotoxicity and degree of inflammation of the sealers in freshly mixed state.

\section{Authors' contributions}

AS. KS and VS. MS. wrote the main manuscript text and AS. KS. NH. prepared and interpreted all the figures. AS. prepared Graphical abstract. All authors reviewed the manuscript AND to have agreed to be personally accountable for the authors own contributions. All authors read and approved the final manuscript.

\section{Funding}

The research was not funded by any organisation. It was self-financed.

Availability of data and materials

The datasets used and /or analysed during the current study are available from the corresponding author.

\section{Declarations}

Ethics approval and consent to participate

The research protocol was presented to Institutional Review Board (IRB) and ethical approval was obtained SRMDC/IRB/2018/MDS/No. 301.

\section{Consent for publication}

Not applicable.

\section{Competing interests}

The authors declare that they have no competing interests.

Received: 19 July 2021 Accepted: 28 December 2021

Published online: 11 January 2022

\section{References}

1. Bernáth M, Szabó J. Tissue reaction initiated by different sealers. Int Endod J. 2003;36(4):256-61.

2. Ricucci D, Langeland K. Apical limit of root canal instrumentation and obturation, part 2. A histological study. Int Endod J. 1998;31(6):394-409.

3. Schaeffer MA, White RR, Walton RE. Determining the optimal obturation length: a meta-analysis of literature. J Endod. 2005;31(4):271-4.

4. Ricucci D, Rôças IN, Alves FR, Loghin S, Siqueira JF Jr. Apically extruded sealers: fate and influence on treatment outcome. J Endod. 2016:42(2):243-9.

5. Diomede F, Caputi S, Merciaro I, Frisone S, D'Arcangelo C, Piattelli A, Trubiani O. Pro-inflammatory cytokine release and cell growth inhibition in primary human oral cells after exposure to endodontic sealer. Int Endod J. 2014;47(9):864-72. 
6. Arun S, Sampath V, Mahalaxmi S, Rajkumar K. A comparative evaluation of the effect of the addition of pachymic acid on the cytotoxicity of 4 different root canal sealers-an in vitro study. J Endod. 2017;43(1):96-9.

7. Scarparo RK, Grecca FS, Fachin EV. Analysis of tissue reactions to methacrylate resin-based, epoxy resin-based, and zinc oxide-eugenol endodontic sealers. J Endod. 2009;35(2):229-32.

8. Petit C, Batool F, Bugueno IM, Schwinté P, Benkirane-Jessel N, Huck O. Contribution of statins towards periodontal treatment: a review. Mediat Inflamm. 2019:6367402.

9. Tsilimigras DI, Sigala F, Karaolanis G, et al. Cytokines as biomarkers of inflammatory response after open versus endovascular repair of abdominal aortic aneurysms: a systematic review. Acta Pharmacol Sin. 2018;39(7):1164-75

10. Tanaka T, Narazaki M, Kishimoto T. IL-6 in inflammation, immunity, and disease. Cold Spring Harb Perspect Biol. 2014; 6(10): a016295.

11. Azuma MM, Samuel RO, Gomes-Filho JE, Dezan-Junior E, Cintra LTA The role of IL-6 on apical periodontitis: a systematic review. Int Endod J. 2014;47:615-21

12. Lin SK, Kok SH, Lee YL, Hou KL, Lin YT, Chen MH, Wang CC, Hong CY. Simvastatin as a novel strategy to alleviate periapical lesions. J Endod. 2009;35(5):657-62.

13. Montecucco F, Burger F, Pelli G, Poku NK, Berlier C, Steffens S, Mach F. Statins inhibit C-reactive protein-induced chemokine secretion, ICAM-1 upregulation and chemotaxis in adherent human monocytes. Rheumatology (Oxford). 2009;48(3):233-42.

14. Loppnow $H$, Zhang $L$, Buerke $M$, Lautenschläger $M$, Chen L, Frister $A$, Schlitt A, Luther T, Song N, Hofmann B, Rose-John S, Silber RE, MüllerWerdan U, Werdan K. Statins potently reduce the cytokine-mediated IL-6 release in SMC/MNC cocultures. J Cell Mol Med. 2011;15(4):994-1004.

15. Sakoda K, Yamamoto M, Negishi Y, Liao JK, Node K, Izumi Y. Simvastatin decreases IL-6 and IL-8 production in epithelial cells. J Dent Res. 2006;85(6):520-3.

16. Tahamtan S, Shirban F, Bagherniya M, Johnston TP, Sahebkar A. The effects of statins on dental and oral health: a review of preclinical and clinical studies. J Transl Med. 2020;18(1):155.

17. Pradeep AR, Thorat MS. Clinical effect of subgingivally delivered simvastatin in the treatment of patients with chronic periodontitis: a randomized clinical trial. J Periodontol. 2010:81(2):214-22.

18. Wong RW, Rabie AB. Statin collagen grafts used to repair defects in the parietal bone of rabbits. Br J Oral Maxillofac Surg. 2003:41(4):244-8.

19. Wong RW, Rabie AB. Histologic and ultrastructural study on statin graft in rabbit skulls. J Oral Maxillofac Surg. 2005:63(10):1515-21.

20. Lee Y, Schmid MJ, Marx DB, Beatty MW, Cullen DM, Collins ME, Reinhardt RA. The effect of local simvastatin delivery strategies on mandibular bone formation in vivo. Biomaterials. 2008;29(12):1940-9.

21. Bertl K, Parllaku A, Pandis N, Buhlin K, Klinge B, Stavropoulos A. The effect of local and systemic statin use as an adjunct to non-surgical and surgical periodontal therapy-a systematic review and meta-analysis. J Dent. 2017;67:18-28

22. Mundy G, Garrett R, Harris S, Chan J, Chen D, Rossini G, Boyce B, Zhao $M$, Gutierrez $G$. Stimulation of bone formation in vitro and in rodents by statins. Science. 1999;286(5446):1946-9.

23. Zhao C, Hu Y, Chen H, Li B, Cao L, Xia J, et al. An in vitro evaluation of the effects of different statins on the structure and function of human gut bacterial community. PLoS ONE. 2020;15(3): e0230200.

24. Mysore, Y, del Amo, E.M, Loukovaara, S. et al. Statins for the prevention of proliferative vitreoretinopathy: cellular responses in cultured cells and clinical statin concentrations in the vitreous. Sci Rep. 2021;11,980.

25. Kamalakannan Preethi O, Sampath V, Ravikumar N, Mahalaxmi S. Comparative evaluation of physicochemical properties and apical sealing ability of a resin sealer modified with pachymic acid. Eur Endod J. 2020;5(1):23-7.

26. Jablonská E, Kubásek J, Vojtěch D, Ruml T, Lipov J. Test conditions can significantly affect the results of in vitro cytotoxicity testing of degradable metallic biomaterials. Sci Rep. 2021;11(1):6628.

27. Kangarloo A, Sattari M, Rabiee F, Dianat SO. Evaluation of cytotoxicity of different root canal sealers and their effect on cytokine production. Iran Endodon J. 2009;4(1):31-4.

28. Huang TH, Ding SJ, Hsu TZ, Lee ZD, Kao CT. Root canal sealers induce cytotoxicity and necrosis. J Mater Sci Mater Med. 2004;15(7):767-71
29. Camargo CH, Oliveira TR, Silva GO, Rabelo SB, Valera MC, Cavalcanti BN. Setting time affects in vitro biological properties of root canal sealers. J Endod. 2014;40(4):530-3.

30. Marthyn P, Beuscart A, Coll J, Moreau-Gachelin F, Righi M. DMSO reduces CSF-1 receptor levels and causes apoptosis in v-myc immortalized mouse macrophages. Exp Cell Res. 1998;243(1):94-100.

31. Trubiani O, Pieri C, Rapino M, Di Primio R. The c-myc gene regulates the polyamine pathway in DMSO-induced apoptosis. Cell Prolif. 1999:32(2-3):119-29.

32. Galvão J, Davis B, Tilley M, Normando E, Duchen MR, Cordeiro MF. Unexpected low-dose toxicity of the universal solvent DMSO. Fed Am Soc Exp Biol. 2014;28(3):1317-30.

33. Araki K, Suda H, Barbosa SV, Spångberg LS. Reduced cytotoxicity of a root canal sealer through eugenol substitution. J Endod. 1993;19(11):554-7.

34. Zafalon EJ, Versiani MA, de Souza CJ, Moura CC, Dechichi P. In vivo comparison of the biocompatibility of two root canal sealers implanted into the subcutaneous connective tissue of rats. Oral Surg Oral Med Oral Pathol Oral Radiol Endod. 2007:103(5):e88-94.

35. Camargo CH, Camargo SE, Valera MC, Hiller KA, Schmalz G, Schweikl H. The induction of cytotoxicity, oxidative stress, and genotoxicity by root canal sealers in mammalian cells. Oral Surg Oral Med Oral Pathol Oral Radiol Endod. 2009;108(6):952-60.

36. Zmener O. Tissue response to a new methacrylate-based root canal sealer: preliminary observations in the subcutaneous connective tissue of rats. J Endod. 2004;30(5):348-51.

37. Cobankara FK, Orucoglu H, Ulker HE. Effects of five different resinbased sealers on L929 and Saos-2 cell viability. J Pediatric Dent. 2013;1(2):37-41.

38. Martinho FC, Camargo SEA, Fernandes AMM, Campos MS, Prado RF, Camargo CHR, Valera MC. Comparison of cytotoxicity, genotoxicity and immunological inflammatory biomarker activity of several endodontic sealers against immortalized human pulp cells. Int Endod J. 2018;51(1):41-57.

39. Diomede F, Caputi S, Merciaro I, Frisone S, D'Arcangelo C, Piattelli A, Trubiani O. Pro- inflammatory cytokine release and cell growth inhibition in primary human oral cells after exposure to endodontic sealer. Int Endod J. 2014;47(9):864-72.

40. Ashraf H, Moradimajd N, Mozayeni MA, Dianat O, Mahjour F, Yadegari Z. Cytotoxicity evaluation of three resin-based sealers on an L929 cell line. Dent Res J (Isfahan). 2012;9(5):549-53.

41. Sousa CJ, Montes CR, Pascon EA, Loyola AM, Versiani MA. Comparison of the intraosseous biocompatibility of AH Plus, EndoREZ, and Epiphany root canal sealers. J Endod. 2006;32(7):656-62.

42. Konjhodzic-Pric A, Jakupovic S, Hasic-Brankovic L, Vukovic A. Invitro comparison of cytotoxicity of four root canal sealers on human gingival fibroblasts. Med Arch. 2015;69(1):24-7.

43. Suzuki P, de Souza V, Holland $R$, et al. Tissue reaction of the EndoREZ in root canal fillings short of or beyond an apical foramen like communication. Oral Surg Oral Med Oral Pathol Oral Radiol Endod. 2010;109(5):94-9.

44. Zhang P, Han F, Li Y, et al. Local delivery of controlled-release simvastatin to improve the biocompatibility of polyethylene terephthalate artificial ligaments for reconstruction of the anterior cruciate ligament. Int J Nanomed. 2016;11:465-78.

45. Stein $D$, Lee Y, Schmid MJ, et al. Local simvastatin effects on mandibular bone growth and inflammation. J Periodontol. 2005;76(11):1861-70.

46. Varalakshmi PR, Kavitha M, Govindan R, Narasimhan S. Effect of statins with alpha-tricalcium phosphate on proliferation, differentiation, and mineralization of human dental pulp cells. J Endod. 2013;39(6):806-12.

47. Chang PC, Chung MC, Lei C, Chong LY, Wang CH. Biocompatibility of PDGF-simvastatin double-walled PLGA (PDLLA) microspheres for dentoalveolar regeneration: a preliminary study. J Biomed Mater Res. 2012;100(11):2970-8.

48. Min KS, Lee YM, Hong SO, Kim EC. Simvastatin promotes odontoblastic differentiation and expression of angiogenic factors via heme oxygenase-1 in primary cultured human dental pulp cells. J Endod. 2010;36(3):447-52.

49. Kim SW, Kang HJ, Jhon M, Kim JW, Lee JY, Walker AJ, Agustini B, Kim JM, Berk M. Statins and inflammation: new therapeutic opportunities in psychiatry. Front Psychiatry. 2019;10:103. 
50. Tolosa L, Donato MT, Gómez-Lechón MJ. General cytotoxicity assessment by means of the mtt assay. Methods Mol Biol. 2015;1250:333-48.

51. Jung JY, Woo SM, Kim WJ, et al. Simvastatin inhibits the expression of inflammatory cytokines and cell adhesion molecules induced by LPS in human dental pulp cells. Int Endod J. 2017;50(4):377-86.

52. Alghofaily M, Tordik P, Romberg E, Martinho F, Fouad AF. Healing of apical periodontitis after nonsurgical root canal treatment: the role of statin intake. J Endod. 2018;44(9):1355-60.

53. Diamantis E, Kyriakos G, Quiles-Sanchez LV, Farmaki P, Troupis T. The antiinflammatory effects of statins on coronary artery disease: an updated review of the literature. Curr Cardiol Rev. 2017;13(3):209-16.

54. Maruo K, Sato D, MacHid T, Kasugal S. Effects of alpha-tricalcium phosphate containing simvastatin on alveolar ridge augmentation. J Oral Tissue Eng. 2010;7(3):143-52.

55. Gupta S, Del Fabbro M, Chang J. The impact of simvastatin intervention on the healing of bone, soft tissue, and TMJ cartilage in dentistry: a systematic review and meta-analysis. Int J Implant Dent. 2019;5(1):17.

56. Chen S, Yang JY, Zhang SY, Feng L, Ren J. Effects of simvastatin gel on bone regeneration in alveolar defects in miniature pigs. Chin Med J (Engl). 2011;124(23):3953-8.

57. Montero J, Manzano G, Albaladejo A. The role of topical simvastatin on bone regeneration: a systematic review. J Clin Exp Dent. 2014;6(3):e286-90.

58. Thunyakitpisal PD, Chaisuparat R. Simvastatin, an HMG-CoA reductase inhibitor, reduced the expression of matrix metalloproteinase-9 (Gelatinase B) in osteoblastic cells and HT1080 fibrosarcoma cells. J Pharm Sci. 2004:94(4):403-9.

\section{Publisher's Note}

Springer Nature remains neutral with regard to jurisdictional claims in published maps and institutional affiliations.

- fast, convenient online submission

- thorough peer review by experienced researchers in your field

- rapid publication on acceptance

- support for research data, including large and complex data types

- gold Open Access which fosters wider collaboration and increased citations

- maximum visibility for your research: over $100 \mathrm{M}$ website views per year

At BMC, research is always in progress.

Learn more biomedcentral.com/submissions 